\title{
INTRODUCTION: THE RETURN OF BERLUSCONI
}

\author{
Paolo Bellucci and Martin Bull
}

In May 2001, for the first time in the history of united Italy and, therefore, for the first time in the history of the Italian Republic, alternation in government occurred as a direct consequence of an electoral victory of the opposition. The incumbent centre left government (the Ulivo - Olive Tree Coalition, led by Francesco Rutelli) was defeated, and a centre right coalition (the Casa delle Libertà, or CDL - House of Freedoms, led by Silvio Berlusconi) began governing Italy with a large parliamentary majority.

It is still too early to evaluate whether this was a 'critical' election for the new Italian political system - one which has effectively set off a hoped-for cycle of alternation between coalitions in government; which heralds a lasting political alignment of voters and parties; and which brings to a close the political transition that began in 1992. Yet it would not be premature to note that the second Berlusconi government - whatever the views of it in Italy and Europe - constitutes an undoubted institutional and political novelty. This is not only because the centre left was electorally incapable of exploiting its incumbency and putative achievements in office against a cohesive right-wing opposition led by a leader of unquestionable (albeit controversial) abilities, but also, and more importantly, because of the potential impact of that leader and his government on policy-making and on the 
very trajectory - economic, social, international and institutional - of the country. Indeed, if it is true that contemporary politics, and especially electoral competition, have become increasingly dominated by personalities and leaders as opposed to parties, then there can be little doubt that Italian politics in 2001 were a talking point on the world scene, largely because of one political personality: Silvio Berlusconi. This volume, the seventeenth edition of Italian Politics, takes stock of the past year. The various chapters assess the nature of and background to the election, the make-up of the new Parliament, the formation and prospects of the new government, the impact of the new government in key policy areas in its initial phase and the government's management of the G8 summit. ${ }^{1}$ This introduction summarises the findings and identifies some common themes.

\section{The 13 May National Elections and Their Impact}

Besides constituting the event of 2001, the centre right's victory in the national elections and the resulting significant parliamentary majority supporting the government have obvious repercussions for both the victorious coalition and the defeated centre left. In relation to the majority, the performance of the coalition overall as well as its main parts - Forza Italia (FI), the National Alliance (AN), the Northern League (Lega) and Biancofiore (Whiteflower) is relevant, since both have implications for Berlusconi's leadership and the executive's scope for action. For the opposition (which did not, in 2001, seem overly eager to explore in any depth the reasons for its defeat), the goal is to build a competitive alternative to the centre right in the medium term by enlarging the electoral space beyond the limits of what has already become an uneasy 'cohabitation' between the Democrats of the Left (DS) and the Margherita (Daisy). While the latter seems capable, albeit with difficulty, of capturing a significant number of centre right voters, the problem for (what remains of) the biggest party of the left is its troubled relationship with the 'antagonistic left' and the diverse anti-globalisation movement which, first in Genoa and then in the Assisi peace march, signalled a new political commitment of the younger generations, which hitherto had been assumed to be individualistic and indifferent to politics.

Despite the widely predicted result overall, certain aspects of the election outcome were not as had been expected. As Diamanti 
and Lazar suggest in their analysis of the vote, we are not faced with a 'largely imperfect bipolarised' party system, i.e. an electoral outcome characterised by an imbalance in support that is clearly in favour of the centre right. The parliamentary majority that emerged from the polls - the result of a semi-majoritarian electoral law which finally seemed to work (for some, perhaps, too much so) - does not correspond to a massive shift in votes to the centre right. The centre right, in fact, lost votes with respect to 1996 ( 2 per cent in the proportional part, 5 per cent in the majoritarian part, including obviously the Lega). Of note is the difference in the centre right's preponderance in the three possible different votes, while still obtaining a majority overall: rough parity with the centre left in the lower house, a certain prevalence in the Senate, where Communist Refoundation (RC) was present in all constituencies, and a massive victory ( 49.5 per cent) in the proportional part. This means that (with due awareness of the caveats mentioned by Diamanti and Lazar) the total number of votes obtained by the Ulivo and those components which (in contrast with 1996) ran independently in 2001 (RC and Antonio di Pietro's Italy of Values) is slightly higher than the total obtained by the centre right. In short, the unequivocal victory of the CDL was achieved in the context of substantial parity between the overall electorate of the two areas, centre left and centre right.

The real difference between the two results is explicable, therefore, in terms of the different capacities of the two coalitions to construct their electoral alliances: a capacity for cohesion in the case of the CDL, and the opposite in the case of the Ulivo. However, this is not to suggest that the centre right is without its share of problems. On the contrary, the notable drop in support for the centre right between the proportional and majoritarian totals highlights, for Diamanti and Lazar, the real characteristic of Berlusconi's leadership - that it is political rather than charismatic. What is important is not 'his personal talents of charm and seduction', since his image did not enlarge the support of the coalition (in fact, it reduced it), but rather his capacity to construct early on, and maintain over time, an agreement amongst centre right parties and to impose the agenda and terms of the electoral confrontation with the adversary. The victory of the centre right, therefore, lay in Berlusconi's aptitude to reorganise his coalition (in the context of an opposing coalition that had difficulty doing likewise) and the ability of the CDL to articulate and project a demand for change. 
The election campaign, as Marletti argues in his chapter, was characterised by the relative absence - rather than centrality - of the use of the mass media. The CDL began what might be described as a 'television non-campaign' very early, at the beginning of autumn 2000. This was part of a long campaign cycle, which is typical of contemporary democracies (and within which the actual election campaign seems to constitute only a brief moment). It was aimed at establishing a general climate of opinion as part of Berlusconi's strategy to portray the election as a 'foregone conclusion' (vittoria annuniciata). There was a radical difference in the nature of this campaign (and indeed in the centre left's campaign), compared with those mounted in both 1994 and 1996. For the centre right, the use of television no longer appeared to be so important, not only because its use was objectively limited by the law on par condicio (providing parity of access for parties) approved in 1996, but also because, for Berlusconi, it was no longer a question of publicising and consolidating a new party in exceptional circumstances and in the short term. It was rather a case of capturing the vote of the undecided or, better still, of those citizens who were apathetic about politics, who were marginal and who did not use, or respond to, the usual forms of political communication, including television. This explains the decision to proceed with a campaign which was reminiscent of the 1940s and 1950s. From November 2000 onwards, cities were carpeted with huge placards that portrayed a smiling and winking Berlusconi accompanied by very simple slogans. These were aimed at attracting the attention of those social groups (pensioners and employees) with which the centre right had experienced some difficulty in the past, and the messages reiterated the idea of the election as a 'foregone conclusion', a message also, paradoxically, accepted by the centre left in its reaction.

The campaign strategy of the centre left appeared uncertain. It began late due to the procrastination over deciding who should be leader of the coalition, but it was also confused, according to Marletti, over the objectives and the message. Should the campaign be aimed at the 'followers' (whose support was already largely secured), or at potential voters who needed their choice to be reinforced (the only ones who, perhaps, could easily be reached through television), or at those who were uncertain and likely to abstain? Should the campaign emphasise the centre left's results in government, or rather counter Berlusconi's promises and accept the idea of the election constituting a referendum on him? 
This uncertainty was further reinforced by the indecision over whether to adopt a strategy of 'demonisation of the adversary' that would exploit Berlusconi's conflict of interest. While some in the coalition argued in favour of the strategy (largely those who would later attribute to it a resurgence in Rutelli's popularity in the final weeks of the campaign), others feared it could end up as a political boomerang. In fact, the whole debate simply focused more attention on Berlusconi.

However, the tentativeness which surfaced in the centre left campaign not only reflected an uncertainty about political marketing, but betrayed the ambivalence with which the centre left Ulivo (some would argue 'post-Ulivo') government presented itself to the electorate after a five-year legislature of centre left governments. This constitutes an important explanation for the defeat (albeit 'honourable') of the centre left, as we argue in a chapter which analyses the post-electoral vicissitudes of the DS and the Margherita. The explanation revolves around the Ulivo both as a government and as a coalition.

First, as a government, the centre left coalition proved unable to present itself as a new type of governing force which, after five years of positive achievements, was seeking re-election. The Ulivo's heyday had, in fact, ended with the fall of the Prodi government. The subsequent D'Alema and Amato governments were only generically from the centre left, and were sustained by the support of political forces which, in 1996, had been in the adversary camp. While this amounted to nothing unconstitutional, it was politically equivalent to nullifying the 1996 electoral mandate. Furthermore, the difficulties experienced in the formation of the D'Alema and Amato governments, and more generally in the formulation and implementation of policies, signalled to a certain extent a return to the practices of coalition governments of the 'First Republic'. As a consequence, in the 2001 campaign both the image and the novelty of the Ulivo government, and the relationship between the coalition and the incumbent government seeking re-election, were lost. The choice of Rutelli (who had not been a member of any government in the legislature) as leader amplified the dilemma. Any possible advantage of the 'incumbency effect' (which would have derived from choosing Amato) was sacrificed to the possible benefits of a telegenic leader who had the capacity to unite (if only symbolically) the centre left.

As a coalition, the Ulivo, during the 13th legislature, failed to develop into the strong and unitary centre left political force which 
had been expected at the outset. This was partly due to policy differences between the constituent parties, but also to the different views on the coalition's future. The extended debate between a social-democratic and ulivista conception of the centre left was not resolved, and neither the transformation of the Democratic Party of the Left (PDS) into the DS in 1998 nor the birth of the Democrats (Democratici) in 1999 made progress towards the birth of a strong centre left party. In short, the Ulivo failed to become an integrated political force and a new type of government. Both of these failures led to a negative image of the centre left, whose policies and achievements were evaluated unenthusiastically by its own electorate, as the ITANES survey has illustrated. This could not but help Berlusconi in projecting the image of the Ulivo as a political force which embodied continuity with discredited policies and practices, in contrast to his own coalition which represented a break with tradition, real change and even the beginning of a new era.

The post-electoral debate in the two main centre left formations was characterised by the inevitable shock that follows defeat. At its Second Congress in Pesaro in November, the DS sought once again its social democratic destiny, which it evidently felt it had not reached under Walter Veltroni at the Turin congress in 2000. While the question as to whether continuity prevailed once again over change remains open, it will not be easy for the DS's new leader, Piero Fassino, to translate an ambiguous mandate into a political line on the three key themes of the congress: political identity, party form and relations with the Ulivo. Programmatic identity appears to be a mere balance (of factions) between variants of reformism ('liberal' or social democratic), and (even with the contribution of Amato) the question of the reunification of the left, as well as how to relate with the Ulivo (and especially the Margherita), remains unresolved. Furthermore, while the Margherita achieved a positive result, the announced (and later postponed) fusion of the four political formations of which it was composed (the Margherita in 2001 was simply an electoral alliance) highlighted the dilemma facing Rutelli as leader of the Ulivo. This dilemma revolves around the difficult relationship emanating from the contradictions of the 2001 electoral legacy for the Ulivo's two principal 'legs': competing with each other electorally, they are at the same time dependent on each other for any future electoral victory and a return to government.

In this difficult partnership, avoiding reciprocal 'cannibalisation' means, for the Margherita, eroding the centre right vote and, 
for the DS, capturing or recovering voters (and parties, through federal forms) on its left (from the Greens to RC). In this context, as indicated by Giovanni Berlinguer's left-wing faction of the DS at the Pesaro congress, what is crucial is the relationship of the party with wide segments of Italian society and, in particular, with the social base that inspires the youth movement (both lay and Catholic), the grass roots organisation COBAS and other social networks which (unexpectedly) emerged in force in Genoa. As della Porta and Reiter argue, the radical nature of this movement lies not so much in its critique of liberalist globalisation as in the political demand for democracy (including supranational democracy). Although the themes of social justice and sustainable development are historically dear to the left, the response in 2001 of the DS and the Ulivo to these demands embodied a refusal to recognise the movement as a legitimate political actor, in this way perhaps neglecting potential new resources of participation and the legitimisation of the demands of the younger generation.

\section{The Second Berlusconi Government}

The size of its parliamentary majority has given the centre right government a significant opportunity to last the full term of the legislature. This is a matter not just of parties and government, but of parliamentary groups as 'institutional projections' of party organisations. As Verzichelli discusses in his contribution, in the extended transformation of the Italian political system, it is the parliamentary groups which have been the real 'sacrificial victims'. They were lacerated by the ruthless indulgence in parliamentary trasformismo during the 12th and 13th legislatures. However, the dawning of the 14th legislature has revealed some evidence of a stabilisation of the party system in the legislative arena, as well as the emergence of an 'adversarial' dynamic, something which has been reinforced by the establishment of a bipolar logic at the electoral level.

From the perspective of the composition of the parliamentary groups, the new legislature has witnessed a more coherent respect (or application) of the majoritarian principle than in 1996, which had been characterised by the crumbling of several groups shortly after the investiture of the two houses. In 2001 the picture was simplified through the establishment of the groups as an 'imperfect quadrille' with two large parties in the two line-ups and some 
smaller formations. Overall, the weight of the five major groups (FI, DS, AN, Margherita and Biancofiore) rose from 78 per cent to 87 per cent in the lower house and 77 per cent to 81 per cent in the Senate. The 'mixed group' (gruppo misto), which had been abnormally large in the past, is more contained, with the number of its components in the lower house reduced to six (from the previous nine). These changes, combined with a reduction in the number of independent candidates, increase the potential for parliamentary stability and discipline, and lie at the root of an evolution - in the party-government-parliament subsystem - of an adversarial dynamic. Verzichelli identifies the first significant parliamentary evidence of this in the control exercised by the groups in the nomination of the leaders of permanent commissions and of the groups themselves - prestigious figures who would be capable of ensuring control of the parliamentary group for the party leadership.

The firmness of the majority's parliamentary leadership is, in fact, a necessary condition for the easy 'navigation' of the government in Parliament and in the country, a theme taken up by Cotta's chapter which analyses the accomplishments, the novelties and the limits of the second Berlusconi government in its first months of activity, contrasting the 2001 experience with the modes of formation of government and their functioning under the 'First Republic'. Undoubtedly, the second Berlusconi government has started life with a solid and original foundation, one which is different not only with respect to the centre left governments that preceded it but compared to all previous governments: it is the first government produced as a consequence of electoral alternation; it has a solid parliamentary majority; and it has a 'direct' electoral investiture which is legitimised by the link between electoral choice and the choice of prime minister (even if constitutionally uncertain, the mechanism is politically sure).

In the period before the elections, Berlusconi had anticipated what was to be his 'presidential' style in carrying out the role of prime minister by indicating that an early decision on his government team would be announced to voters. However, this turned out to be harder than expected (he indicated some names, but even a few of these, such as Pera and Fisichella, ended up with different jobs), something which highlighted the inevitable tensions (in relation to the parties of his coalition and his own political formation) between what Cotta describes as two logics: 'presidential' and 'parliamentary-coalition'. The formation of the government after the elections was a reasonably smooth process in 
terms of its political design, but not in terms of timing and method (the formation of the Prodi government had been quicker and less conflictual). While the modes of government formation in a 'presidential' logic see the coalition leader in a dominant role - he freely chooses his ministers (political or technical) to implement his programme, and they receive a direct investiture from the leader and therefore second-degree political legitimation - government formation in a 'parliamentary-coalition' logic, by contrast, constrains the prime minister's choice of ministers due to the need to maintain agreement among parties of the parliamentary majority, whose prestigious exponents become ministers with 'primary' legitimacy. According to Cotta, the mode and outcome of the formation of Berlusconi's second government leave it as a 'hybrid between government of the leader and government of the coalition'. This was evidenced in a lengthy phase of gestation and disputes with parties which were reluctant to accept the notion of a prime ministerial nominee with unbridled power over the nomination of his ministers. Berlusconi thus 'designated' five technical ministries and awarded FI another nine ministers. This is the part of the team over which the leader exercises rigid control, and which can be used as an instrument of adaptation to changing political conditions (e.g. through reshuffling). The other part of the government is made up of nine ministers belonging to the other parties of the majority, in addition to the Deputy Prime Minister, Gianfranco Fini of AN. For this part of the team Berlusconi will have to maintain a balance between the parties of the coalition.

In terms of the criteria by which any government should be evaluated, Cotta suggests that, beyond a government's capacity to win future elections, there are two: organisational performance and policy performance. Organisational performance refers to the formation of a government and its style of work, something analysed above. Policy performance refers to the government's orientation towards change or continuity in its actions. As Cotta argues, at this stage (with regard to both aspects), the jury is still out on the Berlusconi government. Since it was elected only in May 2001 and is likely to be of long duration, an early evaluation is made more difficult because the government may work at a pace which reflects that assumption. Nevertheless, with regard to policy performance, the government has already shown signs of leadership and the will to carry through changes in several sectors (in both domestic and foreign policy). Consequently, some tentative assessments are possible in certain policy sectors on the basis 
of the Berlusconi government's activity in its initial phase. One can identify various areas of political initiative, partly arising from the government's own agenda and partly as a response to external events. The principal four relate to the economy, federal reform, justice (to be analysed in the final section) and foreign policy; in addition, important developments are worth analysing in relation to education, 'e-government' and agricultural policy.

\section{Domestic Policy}

In relation to the launch of the new government's economic and financial policy (through the so-called ' 100 day plan'), there was an evident attempt by ministers to prepare the ground for a 'strategic retreat' from electoral promises on taxes, pensions and work by declaring an unexpected 'hole in the kitty' (buco di bilancio) inherited from Amato's ('electoral' as it was dubbed) budget - the putative seriousness of which was later qualified. The first principal economic measures of this period, therefore, were the law on the abolition of the death duty and the Tremonti law on removing tax from the reinvestment of all profits. The dialogue with the trade unions and other social actors over the most significant points of the centre right programme (such as labour market flexibility and pensions) turned out to be less conflictual than the experience of the first Berlusconi government in 1994, due to the accommodating approach of the Minister for Labour, Maroni, and the anxieties of AN; at the same time, the approach produced no concrete outcome. Operating within the constraints of the European Growth and Stability Pact, the budget contained provisions (although postponed until 2003) for a reform of the tax system and (one of the CDL's electoral battle-cries) an increase in the minimum pension to $1,000,000$ lire a month, even though the number of pensioners eligible for the rise was smaller than expected. Missing from the agenda in 2001 were any measures regarding further privatisation and safeguarding competition, and there appeared to be some uncertainty about the exact direction to follow with respect to the reform of independent regulatory authorities, measures on large public works and legislation on banking foundations. However, it is still early in the life of the government.

An area in which a decisive reorientation of policy was expected was federalism. However, once the centre left's law on federal reform had been passed by referendum in the autumn, the new 
government was generally cautious and in no hurry to promote a radical form of federalism as had been expected. The government's difficulty was due to the presence in the majority of two parties (AN and the Lega) with incompatible positions on the issue. A complicating factor, however, was that once the centre left's law had been approved, the centre right could not but be more radical in its proposals, something which was actively sought after by Bossi, but with uncertain results. Bossi's federalist proposal was produced only in December, after intense discussions and various changes to the draft. The bill revealed the absence of measures (such as the Chamber of Regions and the reform of the Constitutional Court so as to be elected by the regions) which had been viewed as fundamental to Bossi and his party (which needed a higher profile and more recognition to compensate for its weak electoral support). As Anna Bull analyses in her chapter, the constitutional reform passed by the centre left, on the one hand, and the proposals of the centre right, on the other, were not only incompatible but also incomplete. The constitutional reform of the centre left - a law now in force which the government has in some way to make operational - defines the areas of 'exclusive' legislation of the state (listed in detail), the shared powers of state and regions (also listed), and the 'exclusive' legislative competence of regions in all other matters (not listed). It is a form of co-operative federalism (giving the state the power to ensure minimum standards of service) which nevertheless poses some problems of implementation in its current formulation and embodies the potential for conflict between state and regional levels. On the other hand, the centre right's 'devolution' proposal - a term chosen to signal to 'Padania' the priority being accorded to the regional dimension - is based around a modification to the new version of Article 117 of the Constitution, guaranteeing regions 'exclusive' legislative competence in health, education and local police, and the authority to activate 'primary' legislative powers in all areas currently subject to 'concurrent' legislation. The proposal, inspired by the Spanish model of 'autonomous communities', would introduce a 'variable geometric' system and would therefore open the road to the possibility of different modes and standards of welfare service provision. Evidently, Bossi's proposal is unlikely to be the last word on this theme during the legislature.

A reversal in policy directly attributable to the change in government can be seen in general school policy. Capano's chapter outlines the changes made by the government - even in the 
nature of the minister, a university professor under the centre left governments, and a female manager, Moratti, under the centre right - in response to one of its election promises: to abandon the centre left's proposals of school reform and radically reformulate them. In what amounts to a 're-ideologisation' of school policy, Capano identifies the government's objective as being to reform schools in order to modify some fundamental principles of society itself. This is an ambitious reform whose future trajectory has been outlined by the minister-manager, beginning with the origins of the current crisis of the national education system: a lowering of quality and a lack of choice (between public and private options) for families. Hence, there is an emphasis on the need for rapid and decisive intervention in the sector, to create a new form of 'training for work', and on the importance of 'assessment' as a governing instrument for the educational system.

There has also been a change in the area of administrative reform, through measures regarding the new information technologies and the Internet. The notion of the 'three i's' (impresa, inglese, internet - business, English, Internet) was one of the more effective slogans of Berlusconi's election campaign. Bevilacqua retraces the phases of the previous centre left policy, and then identifies the changes made by the new government in a first set of measures. These shifted the emphasis from 'building the computer network' towards developing integrated services for citizens and business to be accessed telematically. 'E-government' certainly has significant potential in Italy - especially in the context of a broader EU project - but it currently suffers from two factors: first, the involvement of too many entities (state, regions, provinces and communes), each bringing a different vision and jealous of its autonomy in the sector; second, the danger of an accentuation of the digital divide at both the functional (different governmental) and territorial (North/South) levels in the process of technological adjustment and service provision.

Finally, agricultural policy, which was shaken by the 'mad cow' (BSE) crisis in 2001, was characterised by continuity with the change of government. Paradoxically, as Lizzi argues, while Italy was one of the countries least hit by BSE, the impact was greater than in most other countries in terms of a decline in the consumption of bovine meat, economic repercussions and a crisis in the government's management of the sector. The BSE crisis, therefore, became the litmus test for Italian agricultural policy which, in the context of the reformulation of the Common Agricultural 
Policy (CAP), faced the necessity of developing a food quality and safety policy. This is a complex policy due to the need to co-ordinate different levels of government and different types of intervention, as well as meeting environmental regulations and controlling the supply of aid. The young minister Alemanno (of AN) found himself trying to manage a complex area on the eve, moreover, of important changes in the CAP. The entry of new countries with strong agricultural vocations may exacerbate intergovernmental tensions. It remains to be seen how Italy's interests will be 'defined' and promoted.

\section{Foreign and European Policy}

The months prior to and after 13 May 2001 were replete with events not just of a domestic stamp but also of an international nature, the management of which revealed an obvious, but to some extent new, entanglement between the two levels. Foreign policy constituted the area of maximum exposure and difficulty for Berlusconi's government, with obvious effects in the domestic arena.

During the election campaign, this interdependence had surfaced with the stance assumed by The Economist, which - taking almost for granted the outcome of the election - adopted a controversial position on the suitability of the leader of FI to become prime minister (dubbing him 'unfit to rule') due to his conflict of interest, at the heart of which lies his combined role as politician and (inter alia) media entrepreneur, as well as the allegations of which he is accused and the trials in which he is still involved. This theme was rather hesitantly taken up by the centre left, which, as already noted, was internally divided over whether or not to base its election campaign on the 'demonisation' of the adversary. However, the views of The Economist were subsequently voiced by other European newspapers, and this inevitably provoked a series of indignant reactions (some of which were also followed up judicially) by the centre right. It also fuelled rumours about who was behind this attack on the centre right ('hidden powers' or other centre left governments) and instigated an internal debate to which FIAT President, Gianni Agnelli, made an unexpected contribution. Rejecting suggestions that Italy might resemble a 'Banana Republic', he upheld the country's right to non-interference in its domestic affairs, and fully endorsed the centre right leader. This action was followed, after the election, by Berlusconi's nomination of 
Renato Ruggiero, an authoritative former ambassador who is close to the world of FIAT, as Minister of Foreign Affairs.

The internal politics-foreign affairs entanglement continued in the wake of the elections when the new centre right majority had to take decisions (which were inevitably subject to criticism from the opposition on the grounds of both priorities and substance) in an international context that became suddenly tense. The government and the country were thus exposed to a danger which the tenets of Italian foreign policy had long been based on avoiding, even at the price of undermining the country's own national interests: international isolation.

The Prime Minister had counted on the G8 summit in Genoa in July - the first significant international exposure and test for the new government - to assist in the international recognition of his new government. Bayne's analysis shows that, notwithstanding how attention was distracted by the management of the public order issue (see below), the preparations for the summit (inherited from the previous Amato government) and the event itself produced moderately positive results which reflected well on the country. The Italian presidency enabled the summit to focus on developing countries and to pass the Genoa Plan for Africa, the Global Fund for AIDS and Health, and the Task Force on Renewable Energy. While the Berlusconi government could not take credit for the preparatory work (which has traditionally been a weak point of previous Italian presidencies, but this time was undertaken in an innovative and focused way), it is in a position to strengthen, through implementation of decisions taken, the 'Achilles' heel' of summits: the development of subsequent co-operative policies.

Yet there can be little doubt that the relatively positive nature of the results was overshadowed by the 'no-global' demonstrations and the controversial approach to 'conflict de-escalation' used by the Ministry of the Interior during the summit. The Italian approach, according to della Porta and Reiter, is part of a common trend of deviation from prevention and control strategies witnessed in other 'no-global' demonstrations. The issue which arises, therefore, is whether the G8 summit at Genoa might constitute a watershed in the political management of public order, signalling a re-emergence of perceptions of the police as being very sensitive to the political colouring of the majority. Certainly, accusations were made, in Italy and abroad, about the poor management of public order and the Ministry of the Interior's failure to use effective techniques to prevent or defuse conflictual situations. 
If the G8 events created tensions between Italy and her European partners, the government's subsequent legislative measures on justice (and notably the approval of a new law on international requests which, magistrates argue, makes judicial co-operation among states more difficult) became fertile terrain for an unprecedented confrontation in the European arena, and tended to isolate Italy within the European Union. The trial of strength between Italy and its EU partners over the European arrest warrant, in the context of the dramatic circumstances of the struggle against terrorism, highlighted a reciprocal diffidence between the main European countries and the centre right government. Even though the government subsequently retreated on the issue, it did not miss an opportunity to establish a certain distance, if not detachment, from the European arena, e.g. its decision not to participate in the European transport military aeroplane, the veto on a scheduled meeting place for an EU body, the lack of celebrations (combined with explicit doubts expressed by the ministers of the Economy and Defence) over the launch of the euro. This distance was reinforced by simultaneous attempts to publicise the government's political affinity with the United States. Italy's European policy, moreover, led to a second and more serious blow to the government (after the imposed resignation of Justice Under-secretary Taormina) when the Minister of Foreign Affairs, Renato Ruggiero, resigned.

At the root of this reciprocal European diffidence are two related factors. On the one hand, as Cotta suggests in his chapter, the government has experienced difficulties in acquiring international credibility as a result of the heterogeneous image of both the Prime Minister (as politician and businessman) and the governing parties (with respect to the traditional European party families - something which refers primarily to AN and the Lega, since FI is now a member of the European People's Party, EPP). On the other hand, the new government's European foreign policy is 'discordant' with the past and apparently values 'new' Italian national interests while claiming continuity with Italian strategic choices (European and Atlantic). The problem is that the two factors tend to work against each other. International legitimacy may be more difficult to achieve while 'adversarially' pursuing policies which are on a different wavelength from the majority of European policies. A full analysis of the motives for the change of perspective on Europe is still premature. It is open to question as to whether or not it heralds a clear break with the centre left's Europeanism and an orientation towards a 'renationalisation' of foreign policy and Atlanticism. 
While aspects of the new approach were already prominent under the first Berlusconi government (during the war in Bosnia) and when in opposition, it remains unclear to what extent this will continue under the new government. At this point, one can only identify a trend which has yet to be consolidated into a coherent policy regarding future international commitments (beginning with the imminent elaboration of the European Constitution). Nevertheless, on the basis of developments in 2001, the Berlusconi government seems to represent continuity in interpreting the function assigned to foreign policy - traditionally seen in Italy as an instrument for international legitimacy and internal use rather than an arena in which to pursue national interests - but is at the same time innovative in overturning that perspective by using foreign policy to maintain political cohesion in the government majority.

Evidence of this tactic also appeared in the reactions to the major international crises of the year - the terrorist attacks in New York and Washington and the subsequent war in Afghanistan. The risk of Italian marginalisation was avoided, and a climate of international hostility towards Italy, caused by the Prime Minister's (imprudent or perhaps badly interpreted) declarations on Western and Islamic cultures, was overcome. Furthermore, the opposition in obvious difficulty due to the traditional internal divisions on themes such as war and the relationship with the United States supported the participation of Italian armed forces in the war operations. The international crisis probably helped, rather than damaged, Berlusconi. Nevertheless, internal tensions were not limited to the opposition, but affected the majority, too, and Berlusconi did not miss the opportunity of promoting a demonstration in Rome which, while formally meant to be in support of the United States, was, in fact, aimed at reinforcing the cohesion of his coalition.

\section{Justice and the Conflict of Interest Issue}

The domestic area where the new government experienced the most conflict and difficulty in 2001 was that of justice, as evidenced in the legislative measures approved (account fraud, international requests), those measures announced (separation of careers), government declarations (from Minister Castelli to former Under-secretary Taormina) and, of course, the European arrest warrant affair. Space does not permit here a more detailed analysis of judicial policy, but it is worth emphasising the political 
significance of the mobilisation of wide sectors of the magistrature, including its governing organ (the CSM), against many of these measures, the resulting conflicts undoubtedly being fuelled also by imprudent clashes between, on the one hand, individual magistrates and, on the other, representatives of the government and majority coalition. This situation amounts to a serious institutional conflict which has produced tensions even within the majority coalition. If it is not resolved (which will not be easy), the legitimacy and effectiveness of government action could be undermined. It is in this broader context, moreover, that the biggest domestic issue that has confronted Berlusconi and his new government should be seen: his conflict of interest.

The conflict of interest issue is, more than anything else, symptomatic of the extent to which Italian politics in 2001 have been dominated by the 'return of Berlusconi' - understood in the sense of his return to office and a return, therefore, to issues and controversies reminiscent of 1994. As David Hine argues in his chapter, the dilemma posed by Berlusconi's electoral success in 2001 was almost exactly the same as it had been in 1994, simply because the conflict of interest issue had, for various reasons, been unresolved by the previous legislature. There is an inherent conflict of interest between Berlusconi's business interests and prime ministerial office, a conflict beyond (or sometimes within) which lay several others relating to the media, advertising, the judiciary, financial markets and criminal investigations. The range of issues in conflict of interest situations is always complex, but particularly so in the Italian case, because it involves the ownership of assests. Such was its importance during the election campaign (highlighted particularly by comments in the foreign press) that Berlusconi promised to resolve the matter within 100 days of being in office. In fact, this was not achieved; the relevant legislation was not introduced as a government bill until October 2001, and at year's end it was still being discussed by the Constitutional Affairs Committee.

More important than the delay, however, was the substance of the proposed legislation. As Hine points out, the philosophy behind the proposed legislation is fundamentally different from all of the proposals which had been aired in the previous legislature. These had been predicated on a procedural approach, which meant that where a structural or positional situation of an individual embodied a conflict of interest, action was necessary to prevent any possibility of exploitation of that situation by the individual concerned. The new bill, however, adopts a highly restrictive definition of a 
conflict of interest, proceeding on the assumption that a conflict of interest arises only as a result of the particular actions of an individual in a given situation. It follows, therefore, that the key issue is to scrutinise all possible actions of the individual concerned, rather than to divest him of control of the management of his interests while in office - hence, the proposal to establish a new Supervisory Authority (Autorità di garanzia) with the task of examining all government business for potential conflicts of interest. As Hine argues, the new Supervisory Authority (assuming it comes into being) will likely be confronted with so many difficulties in trying to establish unequivocally the existence of conflict of interest 'outcomes' that it is unlikely to be a particularly worrying deterrent to someone like Berlusconi. This was vividly confirmed in 2001 in the new government's policies and decisions towards RAI (Mediaset's direct public-service competitor), and notably those with regard to RAI-way, which Hine uses as an example.

Of course, had this been a relatively unimportant bill and an isolated example of controversy produced by an uncontroversial politician, the risk of exploitation of this legislation by the Prime Minister might be viewed as minimal. Yet Berlusconi's record goes before him, and this issue is part of a series of controversial decisions (especially in relation to the judiciary) taken by the new government in 2001 which have done little but exacerbate that record. Moreover, the conflict of interest issue constitutes Berlusconi's greatest challenge, for it goes to the heart of what is acceptable in an advanced Western democracy and the future development of Italian democracy itself.

The importance of the 2001 elections to Italian politics was noted at the beginning of this introduction. They potentially mark a further step in the gradual 'normalisation' of Italian politics by reinforcing the trend towards bipolarity between two alternating coalitions which (in contrast with the situation in the 'First Republic') involve the majority of Italians (representationally) in government. Yet as Michele Salavati has argued, if this suggests that Italian democracy is no longer 'lame' (monca), it does not, on the other hand, mean that it is necessarily 'good' (bella). For it is also important that 'both coalitions share certain values with regard not only to politics and the economy but, above all, to the functioning of institutions and civil society'. ${ }^{2}$

These values concern such things as limited and accountable government, equality before the law, a political class which is 
neither corrupt nor influenced by private interests, fair regulation of the economy and pluralism in the media, which is protected from undue political influence. Without these shared values, the quality of democracy suffers. If a government rides roughshod over them, the historical gain of achieving alternation between competing coalitions is undermined by the nature of political competition which results. The opposition tends to demonise and delegitimise the government by challenging its right to govern. This in turn can suggest that what has been achieved is not so much alternation in government as the installation of a 'regime'. This is why the fate of the conflict of interest bill and (especially if it is approved) the subsequent actions of the Berlusconi government will be so important in the coming period. Berlusconi needs to demonstrate through his actions that he is committed to consolidating those values essential to the functioning of good democracy. Although it is still too early to judge with any certainty, the events of the first few months of the new government give grounds for scepticism that this will occur during the current legislature. The centre left, on the other hand, needs to confront the government without constant recourse to a strategy of delegitimisation of its adversary, particularly because its own future electoral chances will be influenced by the nature of its actions as an opposition coalition.

(Translated by Claire M. O’Neill)

\section{Notes}

1. The chapters in this volume were presented and discussed at a seminar held at the Istituto Cattaneo on 24 November 2001. We would like to thank the participants of the seminar and the discussants for their useful comments on the preliminary versions of the essays, and in particular: Luciano Bardi, Mario Caciagli, Sabrina Cavatorto, Piergiorgio Corbetta, Alessia Damonte, Mario Diani, Aldo Di Virgilio, Giancarlo Gasperoni, Marco Giuliani, Ettore Greco, Piero Ignazi, Arturo Parisi, Gianfranco Pasquino, Paolo Segatti, Salvatore Vassallo.

2. M. Salvati, 'Conflitti d'interesse e anomalie ecco la democrazia italiana', La Repubblica, 7 August 2001. 
00b 29-48 10/3/02 7:50 AM Page 48 